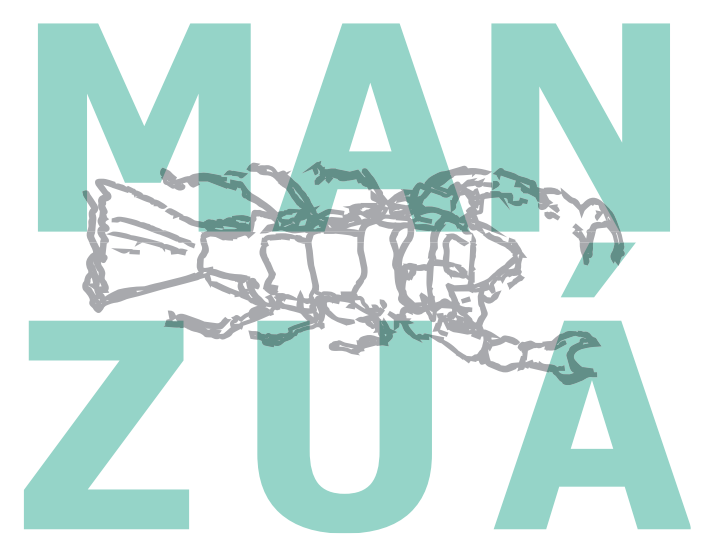

\title{
RASTROS DE UM ENCENADOR EM MOVIMENTO NA MONTAGEM DE "ABOIÁ"
}

\section{Algoniz Alex Cordeiro Diniz}

\section{RESUMO}

$\mathrm{O}$ presente artigo trata da poética da travessia (DINIZ, 2015) como procedimento pedagógico na formação de novos encenadores, para tanto dialoga teoricamente com a "poética do aprender" (COUTINHO, 2018) e a "Pedagogia de Si" (COUTINHO e HADERCHPEK, 2019). Além disso, tendo o Grupo de Teatro Arkhétypos da UFRN como lócus e a experiência como encenador na montagem do espetáculo "Aboiá" o autor reflete sobre sua atuação percebendo aproximações e distâncias entre o encenar e o ensinar.

Palavras-chaves: Pedagogia Teatral, Grupo deTeatro Arkhétypos. Caderno de Encenação, Encenar

\begin{abstract}
This article deals with the poetics of crossing (DINIZ, 2015) as a pedagogical procedure in the formation of new stage directors, for this reason, it dialogues theoretically with the "poetics of learning" (COUTINHO, 2018) and the "Pedagogy of the Self" (COUTINHO and HADERCHPEK, 2019). Also, having the Arkhétypos Theater Group at UFRN as the locus and the experience as a director in the setting up of the play "Aboiá," the author reflects on his performance, perceiving approaches, and distances between acting and teaching.
\end{abstract}

Keywords: Theater Pedagogy, Arkhétypos Theater Group. Performing Arts Event 

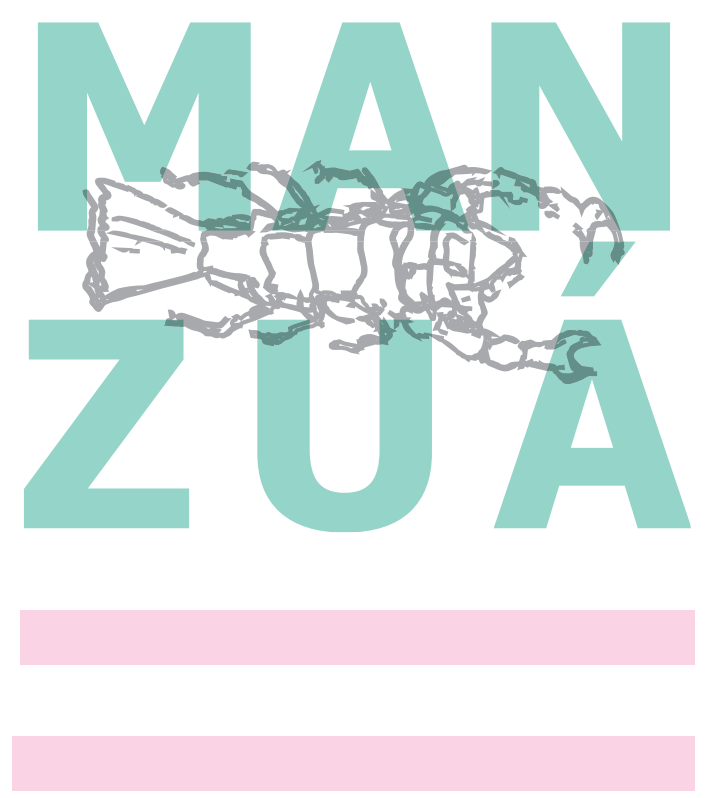

Rastrear um mapa como quem adentra um território poético. Todo processo criativo em potencial apresenta um universo a ser grafado, rabiscado e sentido. Processos criativos constroem territórios simbólicos, cujos habitantes ou transeuntes, rasgam protocolos de sociabilidade e troca afetiva. $\mathrm{O}$ teatro como linguagem sacode a subjetividade. Um olhar inquieto é capaz de identificar as contradições e encontros resultantes de horas de trabalho sensível no espaço ilimitado da linguagem teatral contemporânea. Neste espectro destaca-se o trabalho de pesquisadores no campo expandido das performances culturais e do teatro ritual.

O que escrevo são elementos de uma cartografia que nega a clássica visão do mapa como ferramenta orientadora de percurso. Não há aqui pontos cardeais para encontrar o caminho que levará a uma resposta. Há rastros. Para tanto não serei um historiador que fuça arquivos em estantes e outras gavetas. $\mathrm{O}$ arquivo presente sou eu, assumindo a precariedade que a limitação orgânica do lembrar, do retornar no tempo me possibilita. Oferto apenas as marcas poéticas que me restaram. Falo da rotina de trabalho do Grupo de Teatro Arkhétypos na montagem do espetáculo "Aboiá" entre o ano de dois mil e doze e dois mil e treze.

Portanto são palavras arriscadas, grafadas numa folha digital que branca não é capaz de dar conta das múltiplas cores e cheiros e tatos que 14 pessoas com trajetórias de vidas antagônicas experimentaram em meses de laboratórios criativos na sala 21 do Departamento de Artes da Universidade Federal do Rio Grande do Norte.

Sei da responsabilidade em ressuscitar memórias de um processo, por isso assumo que estamos diante de um território movediço. Falar de Aboiá é permitirse ser invadido por vozes que me transformaram no sujeito que sou: coletivo, político e destinado a mediar aprendizados como 

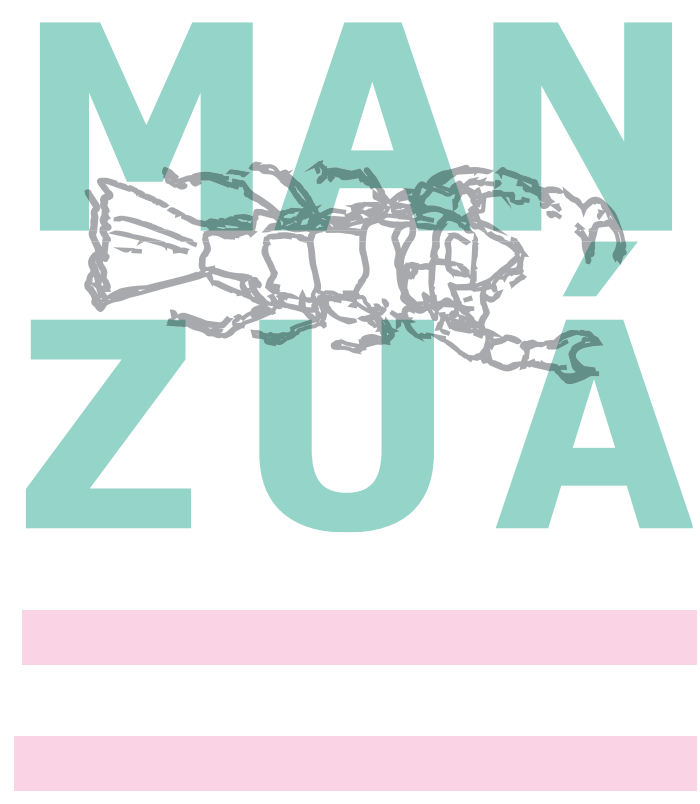

encenador ou como professor. Sou corpo que vivenciou a ebulição sensitiva, explosões subjetivas e políticas que estão instauradas no processo criativo. Digo, todo exercício de dar significado estético numa sala de ensaio deixa marcas. Um grupo de jovens, com distintas visões de mundo, instaurados em uma universidade federal tem suas vidas e corpos modificados após um ano de pesquisa pautado por práticas laboratoriais inspiradas no método de criação denominado jogo ritual (HADERCHPEK, 2018).

Aqui adentrarás no território do eu artista que visita um caderno de encenação caótico aberto em março de dois mil e doze e que reverbera assombros em abril de dois mil e vinte.

Para que saibamos eu e você o território ao qual estamos prestes a adentrar, peço que tenhas apuro sensível na leitura. Estas palavras são arriscadas por tentarem reviver o calor de horas de trabalho em sala de ensaio. Por isso te convido a dar passos na memória de um processo de montagem que teve o universo de vaqueiros que habitam a região Seridó do sertão potiguar como disparador de vontades criativas.

Encenar em movimento é dialogar com os rastros deixados tanto pelo exercício de alteridade existente entre entes de um mesmo núcleo criativo em laboratórios e ensaios de cenas, como com o fantasma, ou seja, o espectro invisível que o espectador no ato de apreciar, não é capaz de acessar. Esse fantasma é o rastro que uma vez surgido em território pueril como no laboratório criativo, some no tempo. Esse escrito tenta o reacender desse rastro.

Teatro é um fio condutor de sensibilidades capaz de subverter ordens instauradas e fissurar o mais duro dos sistemas. Um processo de teatro potente mobiliza além de elementos de linguagem um tipo de instinto político nos sujeitos que pelo teatro são atravessados. A travessia poética do encenador é um ato de despertar desse sujeito que dialoga não só com os vetores 


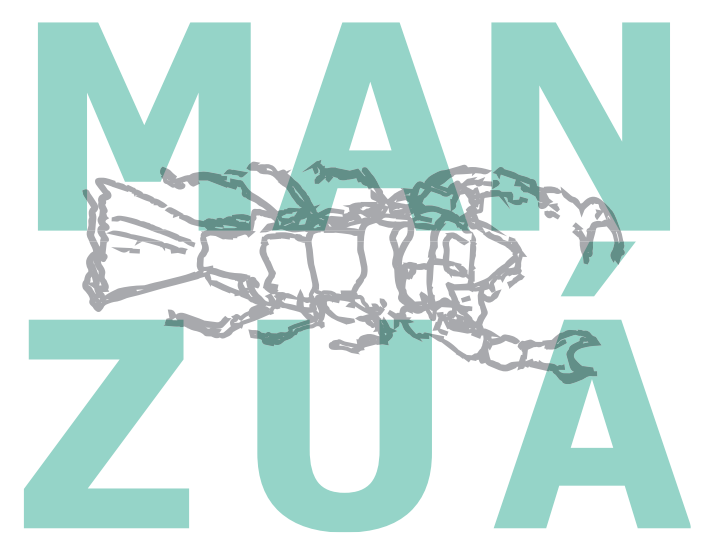

comunicativos de uma cena (luz, som, textualidades...) mas também com as relações afetivas construídas durante o processo criativo e principalmente com o seu próprio despertar.

O "despertar de si" (COUTINHO E HADERCHPEK, 2019) na "poética da travessia" (DINIZ, 2015) requer um jogo de escuta ampliada dos saberes acumulados pelo sujeito, ou seja, o arcabouço cultural grafado na própria pele, associado aos novos saberes que um novo território de criação oferta.

\section{Rastro 1 - O nascer do encenador.}

\section{Digo: o real não está na saída nem na chegada: ele se dispõe para a gente é no meio da travessia. (Guimarães Rosa)}

Aboia mergulhou no universo arquetípico do sertanejo seridoense potiguar mitificando as narrativas sugestionadas entre o boi e o vaqueiro. Temas como morte e ressureição cristã, dominação patriarcal e estigmas da seca compuseram a caótica roda do espetáculo. No processo criativo as energias corporais foram despertadas visceralmente. Nesse dialogo "mitoguiado" (FABRINI, 2012) além do nascer de personagens, brotou também em mim a linha invisível do encenar. Entrei no processo sem uma função definitiva e foi no passo, no trânsito processual que me tornei assistente de diretor. Desse assistir nasceu o encenador.

Encenar é construir sentidos comunicativos do teatro, articular vetores poéticos do construto cênico e potencializar leitura sensorial nos sujeitos da partilha. Enceno na urgência do sentir e, portanto, não hesito em lançar-me no jogo, para no instante do devir, deixar-me poluir pelas sensações corpóreas que o estado de presença suscita e pelo entusiasmo criador que dele posso extrair. $\mathrm{O}$ encenador em movimento age como a agulha de acupuntura poética, provocando 


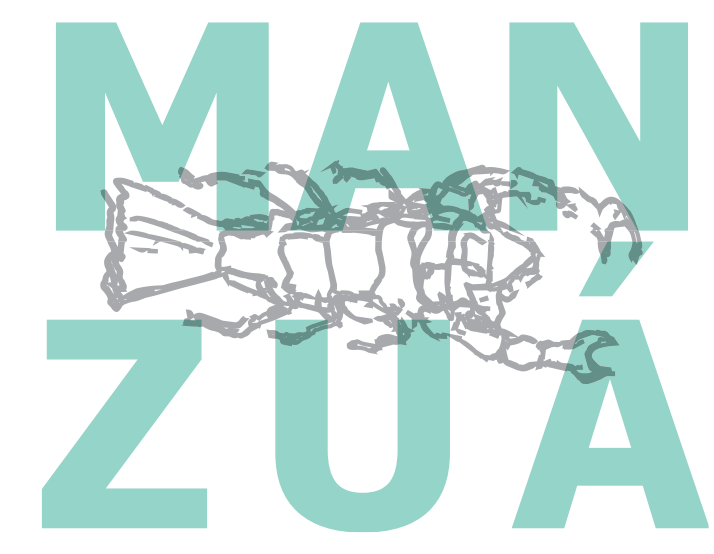

transformações sensíveis no corpo dos atores e atrizes, mediando, com seus procedimentos cênicos, o caminhar dos criadores que partilham da travessia.

A epigrafe norteia meu olhar de nascimento. "Travessia" é processo. Metáfora de que o "real" pode ser concebido como uma poética cênica sublime, ou seja, um modo particular de articular os conhecimentos prévios que o encenador carrega (sua bagagem cultural). Na travessia poética o encenador organiza um encenar próprio.

A metáfora de Guimarães Rosa me ensina que a travessia é preciosa, como artista, devo valorizá-la. Ilustra ainda a força motriz do encenador que desperta o olhar poético ao passo que se expande no território criativo. Um procedimento chave para a criação de Aboiá foi um levantamento iconográfico com fotos de vaqueiros, que alimentaram o imaginário poético de toda a equipe. $\mathrm{O}$ encenador é um ente facilitador de leituras imagéticas, tanto para os atores, quanto para os espectadores. Encenar em movimento é alimentar poeticamente a consciência, a fim de alcançar universos profundos, e fertilizar o território criativo.

Estar em travessia poética supõe um compartilhar de intimidades. $\mathrm{O}$ encenador rasga para o mundo aquilo que o perturba e essa perturbação transmuta-se em algo que o persegue. Caçar. $\mathrm{O}$ encenador tem de usar das artimanhas de um caçador: espreita, faro, aguçamento do olhar. É esse olhar aguçado que o faz perceber um tema, uma imagem que se traduz como metáfora cênica. Vejamos um trecho de meu diário de encenação: "a atmosfera construída na sala tem um quê de profana. O endiabrado põe as mulheres para correr. Uma fuga circular se estabelece e não se sabe quem foge de quem" (grifos próprios). Encenar se dá numa artesania do sensível.

O trecho destacado do diário surgiu na ebulição de um laboratório conduzido por 

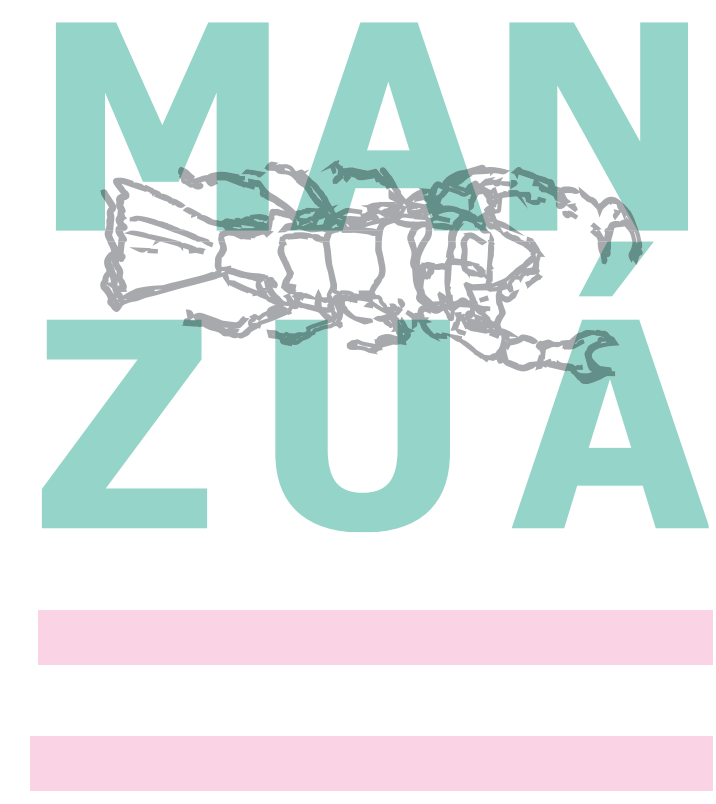

Robson, que se tornaria a cena de abertura do espetáculo. O teatro ritual não opera sobre a ótica da tradição anglo-saxã que tem a palavra como elemento norteador da dramaturgia. A textualidade surge da corporificação dos arquétipos que ganham significado na performatividade adotada pela presença cênica expandida dos atores. O encenador costura sensivelmente os significados, instaurando conflitos e conduzindo o espectador a múltiplas leituras. Teatro é um campo aberto do sentir.

A travessia é uma ação que exige disposição ao arrebatamento, ao desvio, pois é da lente desviada do encenador sobre a geografia formal que é a cena, que saltam as tramas imagéticas da encenação. Travessia é sinônimo de deslocamento pelo processo criativo. Pousa na travessia do encenador o modo de criar, e é isso que está em questão: como o encenador articula sua bagagem cultural em prol de uma poética cênica particular?

O encenador percebe seu potencial a cada passo dado no território da criação. A travessia deixa rastros visíveis que compõe uma gama de procedimentos a serem partilhados. Um elemento chave desse conjunto de procedimentos é o caderno de encenação, já que este guarda segredos, e entre rabiscos e palavras e traços e desenhos, revela o inconsciente imaginativo do encenador, o que podemos chamar de "devaneio poético" (BACHELARD, 2009) do encenador.

O saber do encenador, ou "poética do aprender" (COUTINHO, 2018), é cultivado no ambiente artístico que ele está inserido, fertilizado no diálogo entre seres diferentes, provocando sensações que migram entre o prazer e desprazer, entre o gozar e não gozar, entre o reproduzir uma prática e o não reproduzir: "A direção é uma prática particular porque só se defini em relação a um determinado ambiente teatral" (BARBA, 2010, p. 22).

O teatro tem essa pulsão 


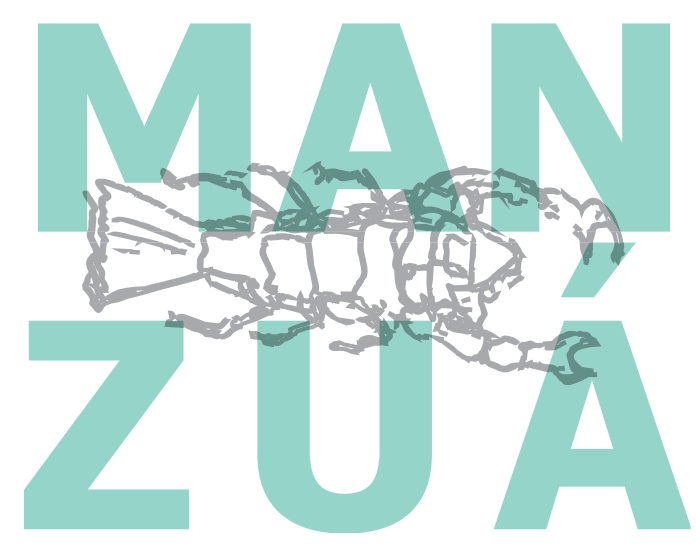

ao coletivo, é no encontro entre seres com subjetividades dispares que se cria um ambiente em ebulição constante, e desse calor se lapidam idiossincrasias artísticas. A supracitada poética da travessia, inspira-se teoricamente na noção de mitodologia em Arte (LYRA, 2014), por se tratar de uma seara de práticas particulares, apta a fazer brotar modos poéticos do fazer. Vejamos:

\section{A Mitodologia em Arte, lida com forças pessoais que movem $\mathrm{o}$ atuante na relação consigo mesmo e com o campo, num processo contínuo de retroalimentação (...) Há assim uma necessidade vital da imagem e da experiência, uma herança de mitologias, que se põe à prova pelo rito. Desse ponto de vista, o símbolo permite estabelecer o acordo entre o eu e o mundo. (LYRA, 2014, p. 177)}

O saber sobre encenação que em mim habita vem dessa tradição em estar posto a dialogar com o grupo de atores e atrizes. As cenas só tomam sentido no corpo de quem se dispõe à exposição.
De nada adiantaria compor um espetáculo sem a pulsão, sem a retroalimentação dos entes que compõe o processo. As figuras arquetípicas que despontaram no círculo simbólico de Aboiá estavam povoadas pelo imaginário do elenco, como registrado no diário de encenação: "Thainá, com o olhar entreaberto, abre os braços que como asas a põe em voo. Ela encara o endiabrado. Diante de mim surge um pássaro da morte ou um galo de briga" (grifos próprios), na trama performativa do espetáculo, a atriz em questão era a carpideira, que presencia a morte, a tragédia e na iminência do embate com o endiabrado, vive em seu próprio choro.

A encenação é um percurso aberto composto por muitas curvas, surpresas e incertezas. Estar em travessia poética supõe um compartilhar de intimidades. Ao criar o encenador rasga para o mundo aquilo que o perturba e essa perturbação transmuta-se em algo que o persegue. Perseguir no sentido de busca. As vezes o encenador 


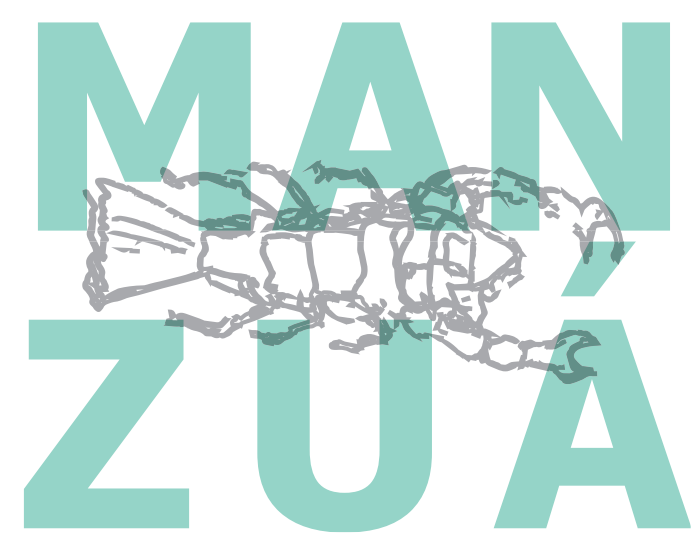

tem de usar das artimanhas de um caçador: espreita, faro, aguçamento do olhar. É esse olhar aguçado que o faz perceber um tema, uma "imagem central" que se traduz como metáfora no espetáculo. A imagem símbolo que constitui-se como a metáfora central, "Muito perto da noção de uma concepção do diretor está a ideia de uma imagem central ou metafórica para a produção teatral (...) Quando tal imagem é escolhida, deve ser prolongada durante toda a peça.” (WILSON, 1981, p. 04).

Retomo a dimensão do encenador como um construtor de símbolos cênicos, um arquiteto de pontes que permitem ao espectador alcançar um ambiente de fricção na cena - já que a interlocução na arte nem sempre pressupõe contemplação, em muitos casos, ela, a cena, impulsiona o sujeito ao contato sensorial. Tal retomada visa clarificar a dimensão de "imagem metafórica”, vejamos Durand, (1988, p. 15),

Não podendo figurar a infigurável transcendência, a imagem simbólica é transfiguração de uma representação concreta através de um sentido para sempre abstrato. O símbolo é, portanto, uma representação que faz aparecer um sentido secreto, ele é a epifania de um mistério.

Ao lidar com o simbolismo das imagens de Aboiá, eu e Robson como encenadores, conduzimos nossas inquietações poéticas por linhas invisíveis, linhas estas transfiguradas no trânsito de corpos. Esse trajeto partilhado configurouse numa arquitetura sensível que permitiu a nossa passagem, como uma vereda, cujo destino é a cena contemporânea, cujo elementos significantes estão abertos e resultaram da subjetividade, do devaneio poético do encenador. A cena é o espaço da transcendência e o mistério reside na leitura do espectador, que recebe a imagem e a lê.

A imagem metafórica da encenação é fruto dessa alquimia misteriosa, desse ímpeto do encenador por ocupar espaços vazios, e transformá-los em 


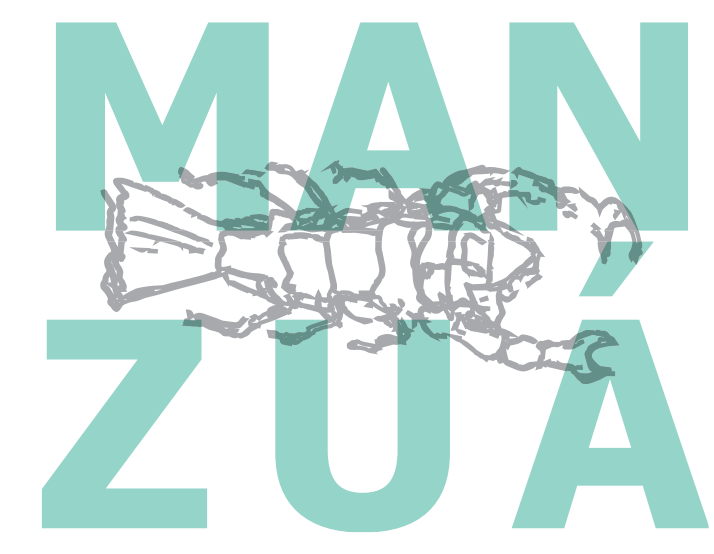

ambientes aptos ao encontro com o espectador, para juntos vivenciarem a cena cósmica, transcendental, essa que se debruça sob a alcova das estrelas, a "imagem metafórica central" como símbolo da encenação, há de se estruturar nas premissas apontadas por Durand (1988, p. 17), afinal,

\footnotetext{
o símbolo é ao mesmo tempo cósmico (ou seja, retira toda sua figuração do mundo visível que nos rodeia), onírico (enraíza-se nas lembranças, nos gestos que emergem em nossos sonhos e constituem a massa concreta de nossa biografia mais íntima) e finalmente, poético, pois apela para a linguagem.
}

Sou um encenador que escreve munido de experiências no teatro de grupo há mais de quinze anos. Revelo no ato de escrever um sujeito que se constituiu em ambientes coletivos. Escrevo com a consciência de que as palavras são rastros, sobras de processos artísticos vividos no território da experiência teatral e que por isso são contaminados de discursos distintos construídos no calor das salas de ensaio, das mesas de estudos, ateliês coletivos. Porém, por mais coletiva que seja a arte teatral, descrever um processo criativo é tarefa solitária. Escrever sobre uma travessia poética é não negar a existência de outras vozes soando no pensamento. $\mathrm{O}$ teatro carrega em si a qualidade transitória do devir. E a escrita do processo é uma tentativa de permanência e construção de memória, logo, a palavra concretiza a memória e constitui-se como uma poética do aprender.

$\mathrm{O}$ encenador em movimento fazferver no caldeirão da diversidade artística os dogmas da cena casta. Como encenador em movimento, em travessia, almejo a metáfora como constructo semeador de encenação. Toda metáfora é uma tentativa de ampliação dos significados dados às coisas do mundo. Encenar é deformar as coisas do mundo, ampliá-las e dar a elas a condição de poesia. Encenar é um ato poético, pois amplia a dimensão imagética da presença 


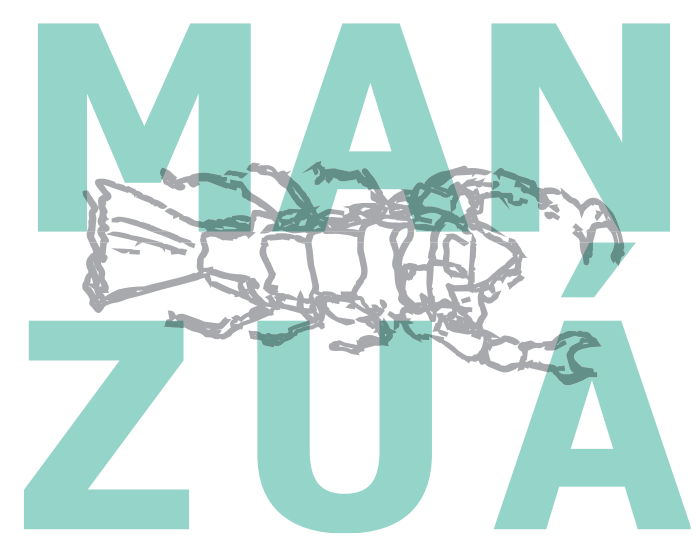

partilhada de humanidades, numa relação entre corpo, espaço e tempo.

Encenar é grafar no vazio, aqui a grafia proferida deixa rastros da poética da travessia de Aboiá. Encenar é agir metaforicamente e dessa ação resulta a experiência. A imagem de um diabo enfrentado a morte me foi um fertilizante poético. Dela retirei material suficiente para junto ao corpo de criadores, estruturar o primeiro movimento do espetáculo. Encenar em movimento é visitar a experiência... "O que nos acontece. $\mathrm{O}$ que nos transforma. $\mathrm{O}$ que nos interpela. Somos esse território de passagem, essa zona de confluência onde distintas forças se interpelam, somos o espaço onde as coisas acontecem, o lugar da experiência. (COLLA, 2013, p. 41)

Toda travessia poética deixa marcas. Alguma reverberação intima é potencializada, seja esta dolorosa ou não. A de dois arquétipos digladiando num curral de bois é tomada de intimidade.
E ao experimentá-la como tema inspirador, aspectos da "carne viva, aos ventos do mundo" (GALEANO, 2011, p. 45) são ofertados e remexidos. Entre encenar e viver há uma linha tênue.

Ao encenar trago à tona fatos e ficções, dores e felicidades da vida. Não é possível desassociar a experiência de quem a vive. A experiência é singular "não pode separar-se do indivíduo concreto em quem encarna" (LAROSSA, 2002, p. 20), ideia que se aproxima da poética da travessia. O encenador ao atravessar a criação encontra os mecanismos possíveis para desenhar a cena. Reconhece como se dá o seu fazer.

\footnotetext{
Fazer significa aqui: sofrer, padecer, tomar o que nos alcança receptivamente, aceitar, à medida que nos submetemos a algo. Ser a "experiência de si" quer dizer, portanto, deixar-nos abordar em nós próprios pelo que nos interpela, entrando e nos submetendo a isso. Podemos ser assim transformados por tais experiências, de um dia para o
} 


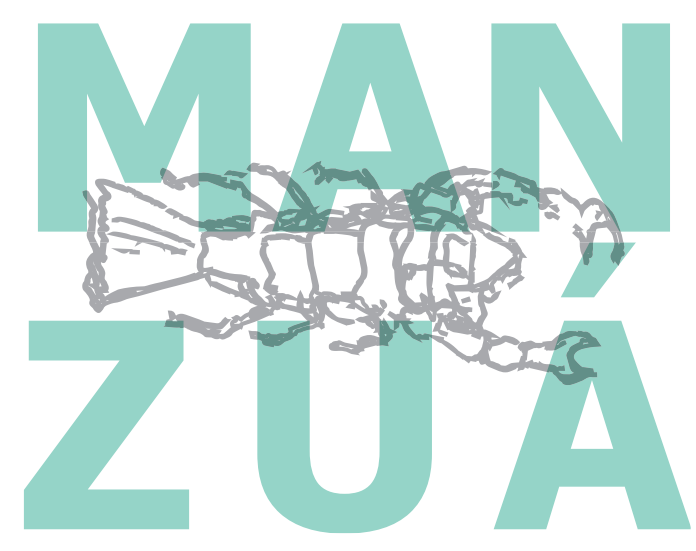

outro ou no transcurso do tempo.

(HEIDEGGER apud COLLA, 2002, p. 41).

Fazer e experimentar são palavras que se familiarizam na mão do artista. Tornam-se irmãs. Ao guiar um processo, me lanço por completo na preparação dos atores. Acabo por assumir uma atitude provocativa, tanto na oferta de "metáforas", como na condução de um jogo. Minha energia é voltada ao fluxo. Não hesito em sentir no corpo a força de uma improvisação em grupo, suando, errando junto. Digo que trago muito do guerreiro, aquele que não teme a luta. A cena não é combativa, sei, mas coragem para estar nela é preciso. E é exatamente essa condição de viver o jogo migrando entre o "conduzir como um olhar externo" (estimulando vocalmente, envolto na atmosfera) e o "conduzir encarnado", (mergulhado no jogo por inteiro, estimulando sem palavra) que dou vida ao a experiência de si em travessia poética.

Há um mito latino-americano de tradição uruguaia. Eis, segundo dizem algumas antigas tradições, a árvore da vida cresce pelo avesso. O tronco e os galhos para baixo, as raízes para cima. A copa afunda na terra, as raízes olham o céu. Não oferece os seus frutos, mas a sua origem. Não esconde o mais entranhável, o mais vulnerável, debaixo da terra, mas o mostra à intempérie: entrega suas raízes, em carne viva, aos ventos do mundo. - São coisas da vida, diz a árvore da vida.

Na sabedoria latino-americana não são folhas dançando ao vento que percebemos na copa, mas raízes, almas no ar. Acredito na força mística da árvore. Ao ler o que escrevo, resquícios de mim te tocam. Resquícios de um encenador que descobre a singularidade da experiência de encenar ao debruçar o corpo num passado vivido a quase dez anos. Quando digo resquícios é na tentativa de ilustrar o que de mais importante sucedeu na montagem do espetáculo "Aboiá", porém, mais do que descrever minuciosamente passo a passo os procedimentos utilizados na 


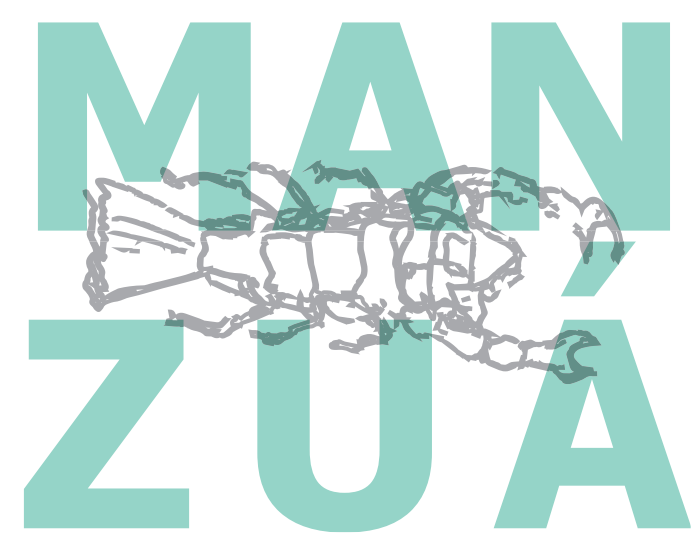

travessia, afim de transformá-los em fórmulas repetíveis, métodos, ofertei ancorado numa linguagem lírica, a experiência da montagem.

Encenar é mediar devaneios e buscar diálogos com o entorno de modo que não sucumba perante as armadilhas da domesticação "O teatro, domesticado pela academia depois de haver sido fagocitado por ela, não estará perdendo sua dimensão verdadeiramente artística, poética e transformadora, a dimensão polivalente e irradiadora das imagens, das metáforas?” (FABRINI, 2013, p. 14).

Fabrini convoca-nos a ajustar a bússola do conhecimento, como num gesto entrópico, que vise perceber as potências nossas sem deixar de lado o exercício autocrítico. Em dois mil e treze, vivemos a experiência de cruzar o oceano e apresentar o espetáculo na Universitat für Musik und Darstellende Kunst Wien (Viena/ Áustria). Em território austríaco eu observava o meu núcleo de convivência, minha comunidade temporária e hoje percebo como nós fomos um ato vivo de desobediência e negamos a domesticação estética. Atitude que foi possível graças à alteridade inconsciente que nos tomava.

O Aboiá impactou os vienenses. Uma experiência coletiva, horizontal e circular. O processo coletivo é circular. Um ciclo caótico de descoberta que revela a intensidade da entrega do artista. Aquele que pulsa com furor, espanto e curiosidade, causará no parceiro de estrada que o acompanha uma admiração e respeito constante. Isso não significa cópia de comportamento, como gostar da mesma música. Basta pulsarem juntos. O Aboiá é uma experiência de contaminação coletiva. Anárquico como Thainá; Rigoroso como Robson; Intenso fisicamente como Lulu; afetivo como Paulinha... É o pedaço de cada indivíduo. Talvez o Arkhétypos seja o lugar da subversão das funções, mesmo sabendo que existe a figura de Robson, o líder, o rio que deságua e toca o lago 

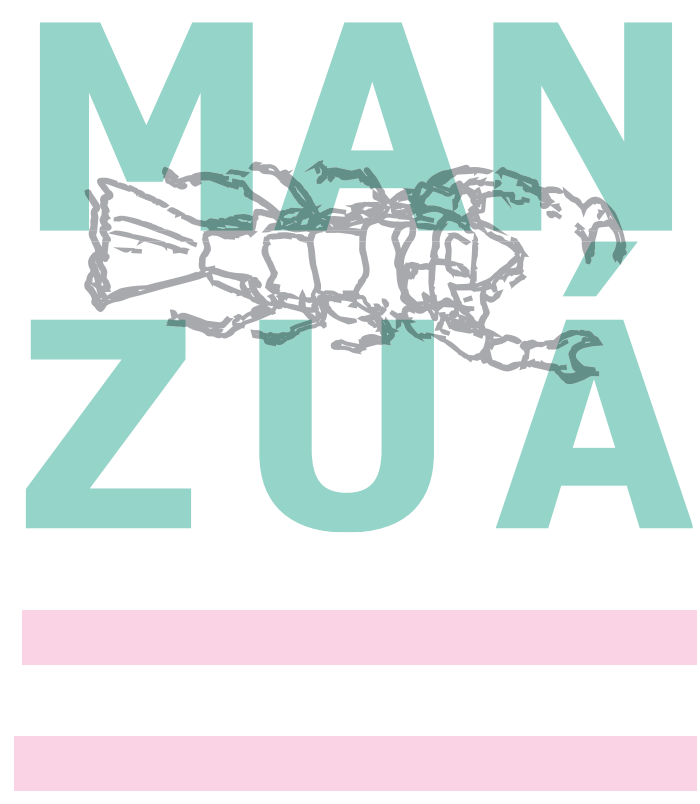

chamado Arkhétypos. Talvez caiba ao lago invadir o rio para auxiliá-lo no ato de fluir (...) As palavras têm dom de devaneio. O artista é um condutor de devaneios, metáforas que provocam beleza e crítica. $\mathrm{O}$ encenador escreve no mundo com as suas metáforas cênicas.

Encenar é mapear as vontades escondidas, como um arqueólogo de si. Reacendo a pergunta de Fabrini "não estará o teatro perdendo sua dimensão verdadeiramente artística, poética e transformadora, a dimensão polivalente e irradiadora das imagens, das metáforas?", e a respondo... Pelo rubro sangue latino-americano, brasileiro, nordestino e periférico que corre em minhas veias, herdado do corpo do meu pai, Manoel, homem de 78 anos, trabalhador rural analfabeto, que como muitos foi obrigado a migrar para a capital e ver seu ímpeto por terra ser calado pelo apito de uma fábrica de tecidos, e de minha mãe, Luzia, mulher de 74 anos, costureira que me inspira o gosto pelo sensível e a resistência que afirmo: não! Que o teatro não torne-se uma ferramenta para domesticar a índole de quem o faz. Antes disso, que o teatro seja uma ponte para o pensamento emancipado. Que deflagre a todos que nele tocam, uma revolução do imaginário.

Que o teatro seja um passo para a metáfora!

\section{REFERÊNCIAS}

BACHELARD, Gaston. A poética do devaneio. São Paulo, Martins Fontes, 2009.

BARBA, Eugenio. Queimar a casa: origens de um diretor. Perspectiva. São Paulo, 2010.

COLlA, Ana Cristina. Caminhante, não há caminho. Só rastros. São Paulo, Perspectiva, 2013.

COUTINHO, Karyne Dias. Por uma didática da improvisação. Em Aberto, Brasília. V. 31, n. 101, p. 121-132, jan./abr., 2018. 

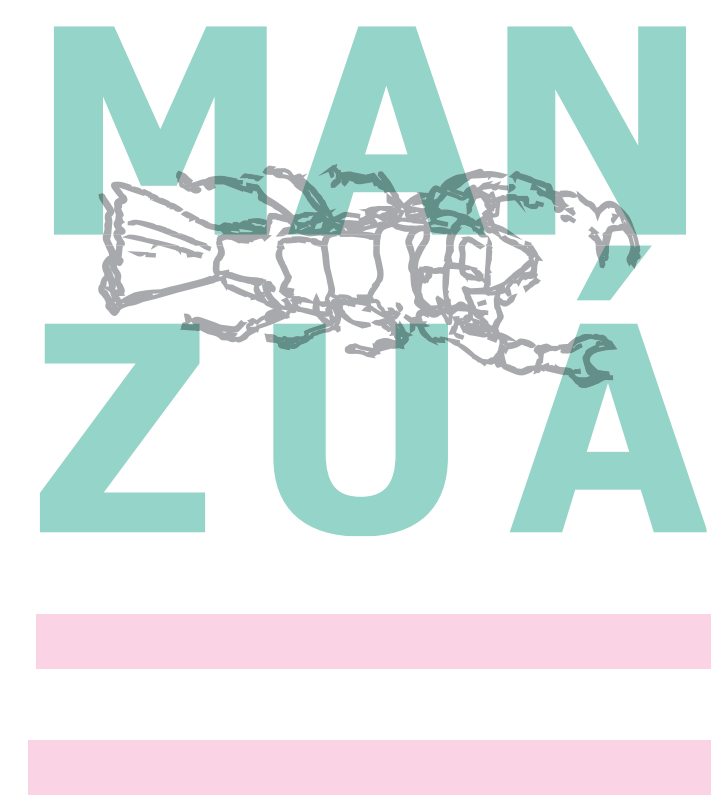

COUTINHO, K. $\quad$ D.; HADERCHPEK, R. Pedagogia de si: poética do aprender no teatro ritual. ARJ - Art Research Journal / Revista de Pesquisa em Artes, v. 6, n. 1, 12 dez. 2019.

DINIZ, Algoniz Alex Cordeiro. Poética da travessia: a topografia do encenador das águas refletida no processo "Memórias de quintal". 2015. Dissertação (Mestrado em Artes Cênicas) - Centro de Ciências Humanas, Letras e Artes, Universidade Federal do Rio Grande do Norte, Natal, 2015.

DURAND, Gilbert. A imaginação simbólica. São Paulo: Cultrix/ EDUSP, 1988.

FABRINI. Verônica. Sul da cena, Sul do saber. In: Revista Moringa. João Pessoa, V 4, N. 1, p. 11-25, jan./ jun., 2013.
Fabrini, V. (2012). Macbeth - Sob a luz desse estranho sol. Shakespeare e Artaud, entre a teatralidade e performatividade. Sala Preta, 12(2), 27-44. https://doi. org/10.11606/issn.2238-3867. v12i2p27-44

GALEANO, Eduardo H. Bocas do tempo. Porto Alegre, L\&PM POCKET, 2011.

LARROSA, Jorge. Notas sobre experiência e o saber de experiência. In: Revista Brasileira de Educação. São Paulo, n. 19, p. 20-28, jan./fev./ mar./abr., 2002.

LYRA, Luciana de Fatima Rocha Pereira de. Artenografia e mitodologia em arte: práticas de fomento ao Ator de f(r)icção. In, 167 Urdimento, n. 22, v. 1, p. 167 180, julho 2014. 